\title{
National Security: Paradigmatic Fundamentals of Research Practices
}

\section{Alexander Viktorovich Dyatlov ${ }^{1}$}

Aues Mukhamedovich Kumykov²

\author{
Anatoly Vladimirovich Lubsky³
}

\section{Anton Vladimirovich Serikov ${ }^{4}$}

\section{Oxana Yuryevna Posukhova 5}

\author{
1 Institute of Sociology and regional studies, Southern Federal University, Rostov-on-Don, Russian Federation \\ 2 Kabardino-Balkarian State University, Nalchik, Russian Federation \\ 3 Institute of Sociology and regional studies, Southern Federal University, Rostov-on-Don, Russian Federation \\ ${ }^{4}$ Institute of Sociology and regional studies, Southern Federal University, Rostov-on-Don, Russian Federation \\ 5 Institute of Sociology and regional studies, Southern Federal University, Rostov-on-Don, Russian Federation \\ Correspondence: Serikov Anton Vladimirovich, Pushkinskaya 160, Rostov-on-Don, 344005, Russian Federation
}

\section{Doi:10.5901/mjss.2015.v6n5s4p266}

\section{Abstract}

The article analyzes paradigmatic fundamentals of national security studies and shows that methodologically these fundamentals are unilateral and do not allow to consider the national security as a holistic phenomenon. The authors argue that the development of the multi-dimensional methodological constructs of national security studies within the neoclassical model of research is a prerequisite for overcoming the methodological unilateralism of the "paradigm of interests" and the "paradigm of values". This model for studying the national security is based on the synthetic use of the methodological capacity of various paradigmatic fundamentals of its research, supplemented with heuristic capabilities of the "soft power" theory, which is considered to induce others to do what is required by the government, without direct violence. In the context of globalization, "soft power" is an important tool for protecting the national security.

Keywords: national security, threats to security, national interests, identity, globalization, paradigmatic fundamentals

\section{Introduction}

In the late modernity era, the following two trends may be identified as the main development megatrends-globalization, which is a serious challenge to national differences (Huntington, 2004; Goldschmidt, 2010), and localization, in terms of which governments are able to reconstruct their national identity (Robertson \& Knondker, 1999), to consolidate the society, and to maintain national security. Mainstreaming national security issues in the modern world makes the search for adequate methodological fundamentals of its research a relevant issue.

Methodological issues of the study of national security were determined by the existing various paradigmatic fundamentals of the researches, which suggest very diverse concepts of national security (Shturba, 2011). Kardashova defines national security as the country's safety, which is conditional upon its ability to reveal (in a timely manner) the emerging threats and to confront them (Kardashova, 2005). According to Bel'kov, national security is a condition achieved as a result of efficient functioning of all social and political institutions in order to create the environment for existence and progressive development of an individual, society and the state (Bel'kov, 1994). Available methodological literature does not cover paradigmatic fundamentals of national security studies.

\section{Methodology}

The methodology for researching the paradigmatic fundamentals of the studies of national security is represented by the conceptual analysis of the existing research practices. This analysis is based on the conceptual thinking that goes 
beyond disciplinary research practices and assumes a holistic approach to their understanding. Conceptual thinking associated with the desire to think of something general through the lens of particular and special things comes from the researcher's initial theoretical ideas about the methodological situation with the studies of national security. These concepts serve as the intellectual preconditions for a holistic perception and understanding of paradigmatic fundamentals of the state-of-the-art research practices used in the national security studies.

Holism of conceptual thinking in terms of methodology is based on the principle of subsidiarity (which means that an indefinite quantity of tasks (of different levels) may be formulated in respect of the subject matter of the study) and on the principle of alternative possibilities and synthetic principle, according to which research problems of a particular class can be solved by using various paradigmatic approaches or on the basis of their synthesis.

\section{Results}

Methodological issues of the study of national security were determined by the existing various paradigmatic fundamentals of the researches, which suggest very diverse concepts of national security (Shturba, 2011). Kardashova defines national security as the country's safety, which is conditional upon its ability to reveal (in a timely manner) the emerging threats and to confront them (Kardashova, 2005). According to Bel'kov, national security is a condition achieved as a result of efficient functioning of all social and political institutions in order to create the environment for existence and progressive development of an individual, society and the state (Bel'kov, 1994). Available methodological literature does not cover paradigmatic fundamentals of national security studies.

A conceptual analysis of contemporary research practices allows to identifying the "paradigm of interests" and the "paradigm of values" as the methodological fundamentals of national security studies.

In terms of the "paradigm of interests", national security means protection of interests of individuals, society, and the state, contributing to sustainable development of the society, or national security means protection of national interests, which contributes to preservation of traditions. According to Collins, national security includes measures taken by a country or a coalition of countries in order to protect their interests from any kind of adverse effects, either external or internal (Collins, 1982). In this regard, national security is interpreted, on the one hand, as protection (from internal and external threats) of various vital interests of individuals, society, and the state, thus contributing to sustainable development of the country (Prokhozhev, 2002); on the other hand, national security is interpreted as the condition of protection (from real and potential threats) of vital national interests in economic, political, military, environmental, information, and other areas.

National security is determined, primarily, by the effectiveness of the country's responses to external and internal challenges, which minimize relevant threats and risks. Challenges mean problems, the solution of which determines the current and future situation in the country. When studying national security in terms of challenges and responses to them, we must proceed from the fact that responses to the challenges represent possible (and not the only) solutions to internal and external problems.

Challenges give rise to threats, which point out to an unknown potential damage, the exact ways to counter which are not established (Baranov, 2004); therefore, such potential damage brings specific risks associated with the need to resolve national security tasks with uncertain outcomes.

External threats to national security are usually associated with: weakening the country's political, economic, and military position on a global or regional scale; geoeconomic, geopolitical, and geocultural expansion of other countries; emergence and escalation of international or regional conflicts; activities of international terrorist organizations; proliferation of weapons of mass destruction and their delivery technologies; desire of certain countries to dominate in the global information space; gaining unauthorized access to information resources; and organization of information warfare.

Internal threats to national security are caused, first of all, by reduction in the country's research and technological capacity, significant reduction in the gross domestic product, innovations, and investment opportunities, economic disintegration; social polarization of the society, increasing social tensions, criminalization of social relationships, growth of organized crime; aggravation of interethnic relations, uncontrolled growth of migration and nationalist sentiments; increased political instability, political and religious extremism, ethno-political separatism; absence of civilian control, corruption of government agencies; schism of values in the society and devaluation of moral values; degradation of environmental awareness and accumulation of environmental problems in the society.

Threats to national security are inextricably linked with potential damage to national interests. Available literature distinguishes between national and public interests. National interests refer to foreign policy, while public interests refer to domestic policy. Therefore, according to Kratochwil, the concept of "national interest" is used to promote foreign policy goals, while the concept of "public interest" is used to augment the public good and protect it from internal challenges 
(Kratochwil, 1982). At the same time, researchers point out that national and public interests are not mutually exclusive. National interests depend on the economic situation, social and political stability, and the moral climate in the country. Public interests are affected by the international situation, the influence of which is especially strong during the periods of its aggravation.

The concept of national interest is being interpreted differently. National interests may be interpreted as a set of moral, political, social, economic, and other needs of the nation, which are of utmost importance for its existence, development and reproduction. Important national interests emanating from the ideas about the nation's goal (mission) and its moral values include protection of the country's sovereignty and territorial integrity, as well as protection of the traditional national way of life ("Natsionalnye interesy..."). National interests may be also interpreted as a set of the country's internal and external needs for security and sustainable development of individuals, society and the state" (Decree of President of Russia dated 12.05.2009 \#537).

Trukhachev believes that national interests represent a set of causal needs and inherent values of a historically developed community, consolidated by social and cultural ties and organized as a state, the protection of which is reasonably required for future existence and development of such community, and such protection is only possible through deliberate joint efforts of its representatives (Trukhachev, 2009).

Broadly speaking, national interests may be interpreted as balanced interests of individuals, the society, and the state in various areas, which are of long-term nature and determine the main strategic goals and current tasks of the country's domestic and international policies.

Globalization, internationalization, and the increasing role of international organizations raises a number of issues related to interpretation of national interests and, therefore, the national security problems faced by certain states. With the tendency to blur the lines between national interests in the modern world, the definition of national interests of a certain country requires mandatory consideration of the interests of other countries, as well as the interests of the entire international community, because this initiates a special mode of social interaction, the logic of which differs from the logic of the market and the logic of the government (Dingwerth \& Pattberg, 2006).

Problems of national interests and, consequently, national security, cannot be studied separately from the category of space. In this regard, methodological problems of national security studies within the geospatial approach (defining, on the one hand, the priorities of research tasks, and, on the other hand, the ways of their solution) are particularly appealing.

As part of the geospatial approach, the subject matters of relevant studies include not only certain regions as spatial areas of conflict and cooperation, but also the processes of geospatial regionalization, accompanied by creation of multiple interacting and competing integration groups. Such groups have the form of voluntary associations of a number of countries in the same region, in order to achieve a declared common goal, usually an economic one. Sustainability and stability of integration groups increase if such countries have common economic and political objectives.

With account of the national interests and national security issues, we may identify three types of such integration groups. The first type is based on bilateral or multilateral intergovernmental agreements of preferential nature. The second type of integration relates to the ability of a regional power to impose its will on the neighboring countries with less economic, demographic, or political capacities, using relatively peaceful, diplomatic (both political and economic) methods. Since regional powers are interested mainly in achieving their political goals, better economic cooperation is treated usually as a side effect. The main factors contributing to creation of such kind of integration groups in other countries include either mutually beneficial economic cooperation (historically inherited or acquired in the new geopolitical and geoeconomic environment), or an external threat. As a rule, relationships in the "regional power-dependent countries" system have an informal basis and are not determined by agreements; therefore, they do not infringe the sovereignty of any country, but provide certain advantages to the regional power. However, we need to take into account the fact that the regional power's position in such an integration group is rather conflicting: on the one hand, it is interested in maintaining certain superiority over the neighboring countries, but, on the other hand, constant maintenance of such superiority may cause an burst of nationalist sentiments or attempts by these countries to revise the policy and find a new patron. The third type of integration groups, known as the "triangle of development", is being created in the border areas of several countries in cases where the integration is very uneven, and cooperation between the countries of these regions outperforms their integration. An integration group may influence the ongoing processes in the region only if it acts in an integral manner; for such purpose, each of its member countries should give up some sovereignty in favor of supranational regional institutions. Strengthening integration raises the limits of national sovereignty, which leads to aggravation of problems related to the national security.

We should mention that geospatial challenges, which contain various threats to national security, represent the issues that need to be solved by governments in a particular region. These problems resulted from a specific geopolitical, 
geoeconomic, geocultural, and georeligious situation in the region. Within the geospatial approach to national security studies, regionalization may be viewed as one of the tools to counteract the adverse effects of globalization, which is a way to maintain relative equality in the world of enormous inequalities in capacities of individual countries.

In terms of the "paradigm of values", national security is considered as protection of national values from various threats. Therefore, the unity of the nation and preservation of its traditions and morality are considered as an essential component of national security. National values are expressed in national standards and national ideals. National standards are specific requirements of national behavior. Functioning of national standards is caused by the need for streamlining social relationships in general. National ideals represent another form of expression of national values. A national ideal may be regarded as a model of social reality and as a supreme goal of social activity. National ideals express the subject's position in relation to the social reality, which is evaluated by the subject from the perspective of appropriate social choice.

National values are also the basis of national identity, which is one of the factors of social consolidation and, therefore, national security. National identity is of collective nature, which means that it represents the identity of individuals comprising such imagined community as a nation. Therefore, from the methodological point of view, we should distinguish between social and collective identities. Social identities result from self-identification of individuals with certain reference social groups; collective identity is the result of individuals' relation to "We" (as an imagined community). The concept of imagined community appeared in the discursive practices due to Anderson, who believed that such a community is a product of the imagination of its members, because they cannot know the majority of their fellows, meet them, or even hear of them, while the image of their community lives in the minds of each of them (Anderson, 2001). It should be emphasized that culture acts as the context of the collective imagination, and its source is represented by the collective memory and various discursive practices.

Their "hard" and "soft" concepts may be identified in the discourse. "Hard" concepts were developed within the essentialist approach to the interpretation of identity. The essentialist idea of identity means that collective identities are defined "naturally". As a methodological orientation, essentialism is described by assigning a permanent set of qualities and properties to a group; therefore, from the perspective of essentialism, identity is something that established imagined communities should have or must seek to have. Moreover, identity is something that one might have unconsciously; so, one might be mistaken in respect of such thing, or such thing can even be "discovered". Such identity is unique and sustainable; it requires a fundamental identity and a "strong sense" as the basis for identification. "Soft" concepts of national identities were developed within the constructivist approach to their interpretation. Because of the constructivists, the idea, according to which identity is not an integral and true essence, not a stable core of ego continuing from the beginning to the end despite external ups and downs, but something ambiguous, movable, multiple, depending on the context, started to dominate in the discourse (Malinova, 2005). Neumann emphasized that identities are movable not only in time and space, but even when they relate to the same subjects at the same point in time and space (Neumann, 1998).

Identities are becoming more numerous, volatile, and dependent on the context. According to the constructivists, it is much more difficult to answer the question "who we are" and maintain (satisfactorily) collective identity as part of everyday life, seeking its recognition by others (Minenkov, 2005). Therefore, the constructivist discourse of identity is not so much about "who we are", as about "what we may be, how others see us, and how it relates to our own view of ourselves". That is why, as emphasized by constructivists, identities are created in terms of representation, and not outside of it (Hall, 1996).

Therefore, collective identities are interpreted (in line with the "soft concepts") as discursive constructs, which led to the conclusion that national identities result from the symbolic struggle or competition of various narratives. However, some researchers point out to the permanent coexistence of several narrative identities, competing with each other for the political market, and the citizens may choose between them (Martin, 1995). As a result, some narratives (cognitive models) of national identity may dominate, while others will get a lower priority; however, the victory can never be considered as final (Roniger \& Sznajder, 1998). Constructivists contributed to establishment of the diverse and relative nature of national identity in the discourse.

At the beginning of the $21^{\text {st }}$ century, the "hard" and "soft" concepts of national identity, developed in terms of essentialist and constructivist approaches, appeared to be heuristically insufficient. This fact drew attention of researchers, who believed that the "hard" concepts of identity, suffering essentialism, actually merge with the language of socio-cultural practices, which makes them unsuitable for analysis; "soft" constructivist concepts mean "too little, almost nothing" (Brubaker \& Cooper, 2000). Because of this, the paradigm of constructive realism (according to which national identity is interpreted as both "natural" (cultural), only, and sustainable, and as "artificial" (constructive), diverse, and volatile) is methodologically promising. The "natural" identity is of unconscious nature; it is built in the process of cultural socialization. The "artificial" identity is built as a result of informed selection of socially significant referents. In this regard, 
national identity, by its very nature, is a result of activities of both the elites and masses (Suny, 2001).

Therefore, in terms of the perspective of constructive realism (which treats identity as a process of constructing the meaning based on a specific cultural property) (Castells, 1997), national identities may be simultaneously interpreted as "artificial" (engineered) and "natural" (cultural). In this regard, we should recognize that, on the one hand, national identities are shaped by socially significant information, and, on the other hand, they are determined by cultural actualization (Harrie, 2006).

Such approach demonstrates the desire, first of all, to show that national identities are not something that exists naturally, in addition to individuals comprising an imagined community of individuals, and to avoid radical essentialization of such identities; secondly, such an approach demonstrates the desire to overcome them and their purely constructivist interpretation, because identities are given not only "artificial", but also cultural, i.e., "natural" dimension. We may distinguish between different forms and sources of national identities. First of all, a "legitimating identity", which is introduced by dominating institutions of the society in order to expand and rationalize their domination over social actors. Secondly, the "resistance identity" shaped by actors who are undervalued or stigmatized by the logic of domination. Thirdly, the "project identity", which is built by social actors on the basis of available cultural material and which redefines their position in the society and focuses on transformation of the entire social structure (Castells, 1997).

The product of the discourse on national identity includes the models of possible collective identities, which are defined by various syncretic images of imagined communities or analytical and synthetic views of them. Models of possible national identities, which are constructed by participants of the discourse, are imposed on social consciousness by entities possessing capital in the form of symbolic power. However, such models become identity matrices if they fit into the mental program of the individuals who make up the imagined community. Therefore, images or perceptions, with which the members of imagined communities identify themselves, not only reflect, but also generate the social reality.

In the era of globalization, the crisis of national identity (which poses a serious challenge to national differences) threatens national security in the context of humanitarian intervention (Inozemtsev, 2013).

\section{Conclusions}

Researchers adhering to different paradigmatic fundamentals focus on important aspects of national security as a social reality. However, methodologically, these grounds are unilateral and do not allow to consider the national security as an integral phenomenon. The development of the multi-dimensional methodological constructs of national security studies within the neoclassical model of research is a prerequisite for overcoming the methodological unilateralism of the "paradigm of interests" and the "paradigm of values". This model for studying national security is based on the synthetic use of the methodological capacity of various paradigmatic fundamentals of its research, supplemented with heuristic capabilities of the "soft power" theory, which is considered to induce others to do what is required by the government without direct violence (Nye, 2006). In the context of globalization, "soft power" is an important tool for ensuring the national security.

\section{Acknowledgments}

This article was written as part of implementation of internal grant No. 213.01-07-2014/15ПЧВГ of the Southern Federal University (Threats to the National Security in the Context of Geopolitical Competition and Patterns of Aggressive and Hostile Behavior of Young People).

\section{References}

Brubaker, R., \& Cooper, F. (2000). Beyond "Identity". Theory and Society. Dordrecht, 29(1), 1.

Castells, M. (1997). The Power of Identity, The Information Age: Economy, Society and Culture (Vol. 2, pp. 6-8). Cambridge, MA; Oxford, UK: Blackwell.

Collins, J. M. (1982). U.S. defence planning. A critique (pp. 309). Boulder, Colorado: West-view Press.

Roniger, L., \& Sznajder, M. (Eds.) (1998). Constructing Collective Identities and Shaping Public Spheres: Latin America Paths (pp. 103143). Brighton: Sussex Academic Press.

Dingwerth, K., \& Pattberg, P. (2006). Global Government as a Perspective of World Politics. Global Government, 2, 188.

Hall, S. (1996). Introduction. Who Needs "Identity"? In S. Hall, \& G. P. Du (Eds.), Questions of cultural identity (pp. 4). Leningrad: Sage.

Harrie, G. (2006). European identity-implications from the social theory of Norbert Elias. European Identity: Theoretical Perspectives and Empirical Insights (pp. 59-90). Berlin: LIT Verlag Munster.

Kratochwil, F. (1982). On the Notion of "Interest" in International Relations. Inter-national Organization, XXXIV, 2. 
Martin, D. C. (1995). The choices of identity. Social identities. Basingstoke, 1(1), 5.

Neumann, I. (1998). European identity, EU expansion, and the integration/exclusion nexus. Alternatives. Boulder, $23,400$.

Suny, R. G. (2001). The Empire Strikes Out: Imperial Russia, "National" Identity, and Theories of Empire. In R. G. Suny, \& T. Martin (Eds.), A State of Nations: Empire and Nation-Making in the Age of Lenin and Stalin (pp. 8). Oxford: Oxford Univ. Press.

Anderson, B. (2001). Imagined Communities (pp. 26-32). Moscow: Kanon-Press-C; Kuchkovo Pole.

Baranov, N. A. (2004). Political relations and political process in modern Russia. Saint Petersburg: BGTU. Retrieved from http://www.society.polbu.ru/baranov_politics/ch153_i.html

Bel'kov, O. A. (1994). Conceptually-categorical apparatus National Security Concept. Security: Information Collection: Foundation for National and International Security, 3, 91.

Inozemtsev, V. L. (2013). The Lost Decade (pp. 296-301). Moscow: Moskovskaia shkola politicheskikh issledovanii.

Kardashova, I. B. (2005). On categorical conceptual apparatus of the theory of national security. Russian Investigator, 5, 53.

Malinova, O. J. (2005). Study the policy and the discourse of identity. Political science: Identity as a factor in politics and the subject of political science, 3, 12-13.

Minenkov, G. Y. (2005). Identity politics in terms of modern social theory. Political science: identity as a factor in politics and the subject of political science, 3, 23.

Nye, J. (2006). "Soft power" of the state. East, 5(41). Retrieved from http://www.situation.ru/app/j_art_1165.htm

National interests. War and Peace in the terms and definitions of military-political vocabulary. Retrieved from http://www.voina-imir.ru/article/20

Prokhozhev, A. A. (2002). The general theory of national security (pp. 22). Moscow: Publishing House of RAPS..

Trukhachev, V. V. (2009). National interests: nature, structure, political mechanisms of formation. Modernity and Political Sciences (pp. 41-53). Novosibirsk: TsPI-Izdatel'stvo SIBPRINT.

Presidential Decree of 12 May 2009 N 537 "On National Security Strategy of the Russian Federation until 2020". Russian Newspaper, 4912. Retrieved from http://www.rg.ru/2009/05/19/strategia-dok.html

Tsygankov, P. A. (2002). Theory of international relations (pp. 288-298). Moscow: Gardariki.

Shturba, E. V. (2011). Historiography, Sources and methodology of the study of public policy in the sphere of ensuring the national security of the Russian Federation. Historical and socio-educational thought, 1-2, 20-51.

Huntington, S. (2004). Who Are We? The Challenges to America's National Identity. New York: Simon \& Schuster.

Goldschmidt, P. (2010). Europe's Identity Crisis. The New York Times.

Robertson, R., \& Knondker, H. (1999). Discourses of globalization: Preliminary considerations. International Sociaology, 13(1), 25-40. 